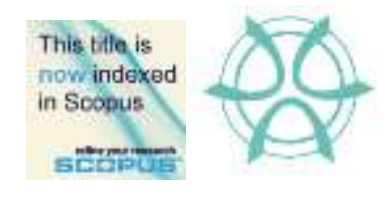

\title{
ANALYZING THE SPATIAL TEMPORAL OF PROPERTY CRIME HOT SPOTS. A CASE STUDY OF KUCHING, SARAWAK
}

\author{
Norita Jubit $^{1}$, Tarmiji Masron ${ }^{2}$, Azizan Marzuki ${ }^{3}$ \\ ${ }^{1,2}$ Centre for Spatially Integrated Digital Humanities (CSIDH), \\ Faculty of Social Science and Humanities \\ UNIVERSITI MALAYSIA SARAWAK \\ ${ }^{3}$ School of Housing, Building \& Planning, \\ UNIVERSITI SAINS MALAYSIA
}

\begin{abstract}
This study aims to determine the monthly hot spots of property crime in Kuching, Sarawak from January-December, 2015-2017. Hot Spot Analysis (Getis Ord Gi*) was chosen for this study because it can detect the areas that have spatial clustering with similar values around its neighboring boundaries. It can present an output for hot spots and cold spots with different levels of statistical significance. Gita Police Station sector boundaries were identified as a high-value cluster for eight months in 2015 and also have a high-value cluster for seven months in 2016. However, in 2017 Padungan Police Station sector boundary was identified as a high-value cluster for four months. The hot spots of property crime in Kuching, Sarawak change over time and places. This study found that holidays and festivals are exogenous factors that can influence the increases of property crime rate in Kuching, Sarawak. The findings of this study can help police to predict temporal crime trends accurately which would be beneficial for management planning.
\end{abstract}

Keywords: Spatial Temporal, Property Crime, Getis Ord Gi*, Kuching

${ }^{1}$ Postgraduate (PhD) at Universiti Malaysia Sarawak. Email: noritajubit90@gmail.com 
Norita Jubit, Tarmiji Masron \& Azizan Marzuki

Analyzing the Spatial Temporal of Property Crime Hot Spots. A Case Study of Kuching, Sarawak

\section{INTRODUCTION}

Urbanization is a global trend that has brought about development to major urban areas in most metropolitan cities around the world. This trend has also resulted in high level of crime in urban areas (Chen et.al, 2016). The rapid urbanization process has been identified as the cause of insecurity in urban areas and the prevalence of crime is rampant in developed and developing countries (UNHABITAT, 2007). In Malaysia, there is a high level of property crimes including daylight burglary, night burglary, lorry-van theft, car theft, motorcycle theft, bicycle theft, and snatch theft being reported. Property crime is the major contributor to the index crime over violent crime in Malaysia (Ghani, 2017; Muhammad Amin et.al, 2014; Muzafar and Law, 2008; Nor-Ina Kanyo et.al, 2017). Some areas are more prone to crime and crime incidents are not randomly distributed as well as crime hot spots do exist within city boundaries (Cozens et.al, 2005; Marotta, 2017; Garnier et.al, 2018).

Today crime mapping and spatial analysis are far useful to understand where crime activity is likely to occur (Guven and Gercek, 2018). Today planners utilize GIS around the world in a variety of applications. GIS tools can provide the necessary planning platform for visualization, modeling, analysis and collaboration (ESRI, 2011). GIS has seen significant developments in research areas such as crime analysis, police station placement, and crime reduction strategies (ESRI, 2019). GIS is employed for developing, storing, managing, analyzing, and visualizing spatial data and non-spatial data-related activities (Tarmiji et.al, 2015). Studying crimes using spatial analysis and temporal distribution is very important because information about the occurrence of crime is the most essential tool in preventing crime in urban areas (Yar and Jamal, 2016).

Previous research related to monthly spatial and temporal analysis of crime mostly focusing on the relationship between crime and climatology, timespace, seasonal pattern, air pollutants, water quality, dengue fever, road accidents and casualties, characteristics of rainfall, the pattern of mass flowering, and Phytoplankton during monsoon season (Mohd Nasir dan Janusz, 1996; Zaini and Noor Shah, 2010; Siti Aekbal et.al, 2012; Mohd Ekhwan et.al, 2015; Norziha, 2015; Mohd Shafiq et.al, 2016; Shamsuddin et.al, 2015;).

This paper aims to analyze the spatial and temporal of property crime hot spot in Kuching, Sarawak by using the police station sector boundaries as the unit of analysis. The findings of this research revealed that the property crimes of both spatial and temporal trends are related to festivals and holidays.

\section{LITERATURE REVIEW}

Luo (2017) explored the patterns of burglary crimes at multi-spatiotemporal scales in Chicago between 2006 and 2016. The objective of this study was to 
indicate how the clusters shifted in space and time by using Getis Ord Gi*. There were some areas detected that have high-value clusters by month and weekdays. One police district was identified as a high-value cluster for nine months. Norita Jubit et.al, (2019) in their study also used Getis Ord Gi* to explore property crime hot spots in Kuching, Sarawak. The result found that the tool can help to detect the changing of hot spots of property crime (2015-2017) by police station sector boundaries.

Yar and Jamal (2016) conducted a study on crime with special reference to its spatial and temporal distribution in Mardan City of Pakistan using hot spot analysis and revealed that most crime occurs during summer (May to September) with a total of 5 hot spots. The finding of their study found that when the weather gets hot people tend to get mad more easily and would lead them to lose their tempers.

Bold and Borg (2016) used the aoristic analysis method in GIS to conduct a temporal analysis of home-based case analysis in Sweden from 1 January 2010 to 31 December 2014. Their study found that aoristic methods are best suited to estimate the frequency of home-based crime over time when data is limited. Andresen and Malleson, (2015) also using spatial point pattern tests to investigate the differences in spatial and temporal patterns of criminal events for some different types of crime in the City of Vancouver British Columbia. The study found that crime increases during the summer months and occurs mostly during weekends.

Valente, (2019) found that crime concentration changes over time depending on temporal dimensions such as the season, day of the week and the hour of the day in the Brazilian state capital. Fan, (2014) used kernel density analysis and nearest neighbor hierarchical clustering (NNHC) to predict crime in the city of Houston and found that temporal-spatial analysis showed that crime occurred more frequently during September to December of 2011 in central and southwest Houston.

Tarmiji Masron et.al, (2020) conducted a study on spatial distribution of Universiti Malaysia Sarawak (UNIMAS) students and COVID-19 pandemic and found that GIS technique was able to screen students based on their origin and location. Zaini and Nor Shah, (2010) conducted a study on Safe Cities in Malaysia using aoristic analysis techniques in GIS to identify non-specific crime incidents. Mohd Ekhwan et.al, (2015) conducted a study on spatial and temporal assessment of drug addiction using multivariate analysis and GIS.

The result found that a cluster analysis helped to identify areas of drug problems in Terengganu, Peninsular Malaysia. Siti Aekbal et.al, (2012) also used kriging, buffer and overlay analysis to investigate the relationship between burglary and temperature in Shah Alam Selangor. The finding indicated that there is a correlation between hot spot area from burglary activity with the surrounding climatology behavior. 
Norita Jubit, Tarmiji Masron \& Azizan Marzuki

Analyzing the Spatial Temporal of Property Crime Hot Spots. A Case Study of Kuching, Sarawak

\section{STUDY AREA}

Kuching is the most populated city in Sarawak with a total population of 598, 617. Besides that, Kuching has also relatively high industrial productivity and has a high share of manufacturing with 58\% (World Bank, 2015). The case study has been selected because Kuching was reported to have the highest property crime rate compared to other districts in Sarawak. In 2015-2017, Kuching has recorded 4,123 cases $(81.3 \%)$ of property crime while violent crime was about $18.6 \%$. For this study, 9 police station boundaries have been identified such as (1) Santubong, (2) Gita, (3) Satok, (4) Sentral, (5) Sungai Maong, (6) Padungan, (7) Tabuan Jaya, (8) Bintawa and (9) Sekama. Kuching District Police Headquarters divided each boundary of police stations into 57 sector boundaries as shown in Figure 1.

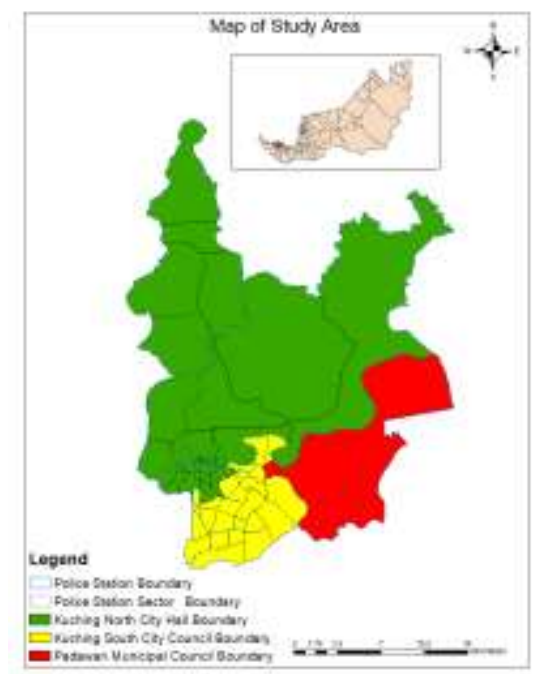

Figure 1: Map of Study Area

\section{DATA COLLECTION}

The study was first approved by the Criminal Investigation Department, Bukit Aman. The spatial data was obtained from the head of the police station in Kuching including Kuching district boundary, road data, police station boundaries and police sector boundaries. The non-spatial data was collected from Kuching Criminal Investigation Department and Kuching Headquarters Police District which include data of Property Crime (2015-2017) that were categorized by month, location and address of property crime occurrences by police station. The geocoding of the property crime data was carried out based on the address of the crime occurrences because the property crime report obtained from the Police Reporting System only has the address of the incidents without any reference of the coordinates on the ground. The geocoding process is very important to allow 
the distribution of property crime to be displayed on the map and enabled spatial analysis to be conducted.

\section{METHOD}

Getis Ord Gi* was chosen for this study because this technique can identify an output hot spot and cold spot with different levels of statistical significance between 90\% (p-value $<0.10), 95 \%$ ( $p$-value $<0.05)$, and 99\% (p-value $<0.01)$ respectively (Martin et.al, 2019). Besides that, it also can detect the areas that have spatial clustering with similar values around its neighboring boundaries. Other clustering analysis such as Kernel Density Estimation (KDE) only can show the location of the cluster but it cannot tell whether the clusters are significant or not (Li et.al, 2017). Local Indicator Spatial Autocorrelation (LISA) can confirm the clusters with different levels of statistical significance but it is more efficient at identifying the outliers (Liet.al, 2017).

Getis Ord Gi* is a local spatial statistic that consider each feature or polygon (Luo, 2017). This method was used to identify high and low crime cluster values determined through three outputs namely (i) z-scores (ii) p-values and (iii) confidence levels for each polygon. The Getis Ord Gi* statistic is a zscore that measures whether a crime occurs with high or low cluster values. Significant statistical value is that when the $\mathrm{z}$-score is positive $(+)$, the greater or higher the z-score value the higher the density of the high-value group (hot spot). For z-scores that indicate a negative (-), the smaller the z-score the higher the diversity of crime groups with low scores (cold spot) (Matijosaitiene et.al, 2019).

\section{FINDINGS}

Figure 2 shows the total crime incidents by month at Kuching Sarawak from 2015-2017. From the statistics, the result shows the property crime tends to be higher in February with 184 cases and 132 cases in 2015 and 2017 respectively.

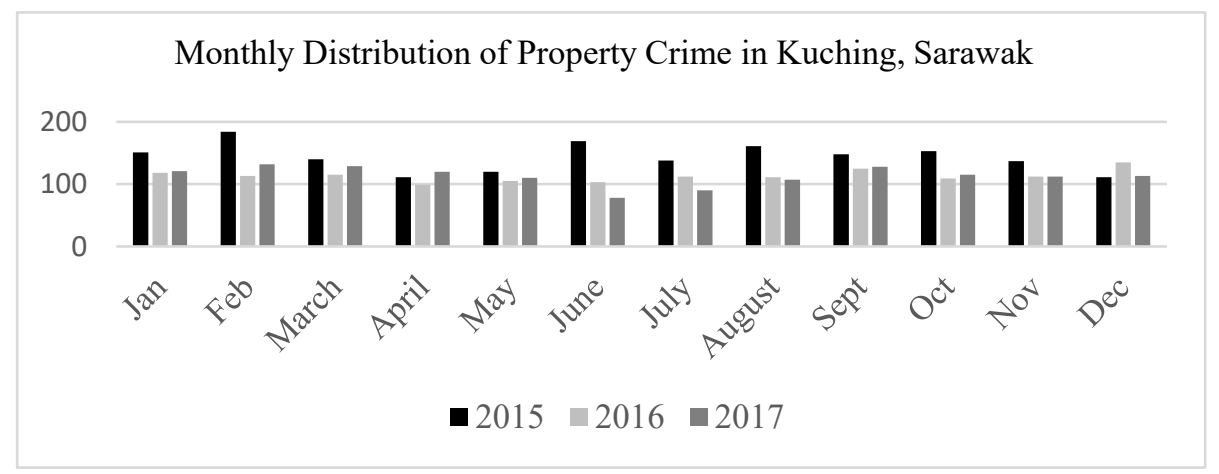

Figure 2: Monthly Distribution of Property Crime in Kuching, Sarawak Source: Kuching District Police Headquarters (2018) 
Norita Jubit, Tarmiji Masron \& Azizan Marzuki

Analyzing the Spatial Temporal of Property Crime Hot Spots. A Case Study of Kuching, Sarawak

In 2016, the property crime was reported higher in December with the total incidents of 135 cases. This shows a high and increasing rate during the festival season. Minister of Welfare, Community Wellness, Women, Family, and Child Development Datuk Fatimah Abdullah said that criminal activity will not stop immediately even during the festive season, but will continue to grow if not monitored and controlled (Borneo Post Online, 2019). Festival events are good examples of crime generators (Cohn and Breetzke, 2017).

\section{HOT SPOTS OF PROPERTY CRIME FROM JANUARY TO DECEMBER IN 2015-2017}

Figure 3 shows the spatial temporal hot spots of property crime in Kuching, Sarawak from January to December, 2015-2017. Results found that Gita Police Station sector boundaries were identified as a high-value cluster ( $p$-value $<0.01$ ) which were considered as significant hotspots at $99 \%$ confidence level for eight months (January, February, March, April, May, August, September and November) in 2015. Gita Police Station sector boundaries were also identified as a high-value cluster (p-value $<0.01$ ) for 7 months (February, April, June, July, August, September and October) in 2016. Thus, Gita Police Station has been identified as the high-value cluster concentrated in Kuching North City Hall boundary during 2015 and 2016.

However, only two sectors in Santubong Police Station boundary was classified as cold spots in January 2016 as shown in Figure 3, while Sekama Police Station sector boundaries were identified as a high-value cluster ( $p$-value $<0.01$ ) for four months (March, April, November and December) in 2016. The result also reveals that sector 2 at Padungan Police Station boundary was identified as a high-value cluster ( $p$-value $<0.01$ ) for four months (January, March, May and June) in 2017. However, it was reported that both Gita Police Station boundary and Sekama Police Station boundary have high-value clusters (p-value $<0.01$ ) for three months in 2017 as shown in Figure 3. 
PLANNING MALAYSIA

Journal of the Malaysia Institute of Planners (2020)
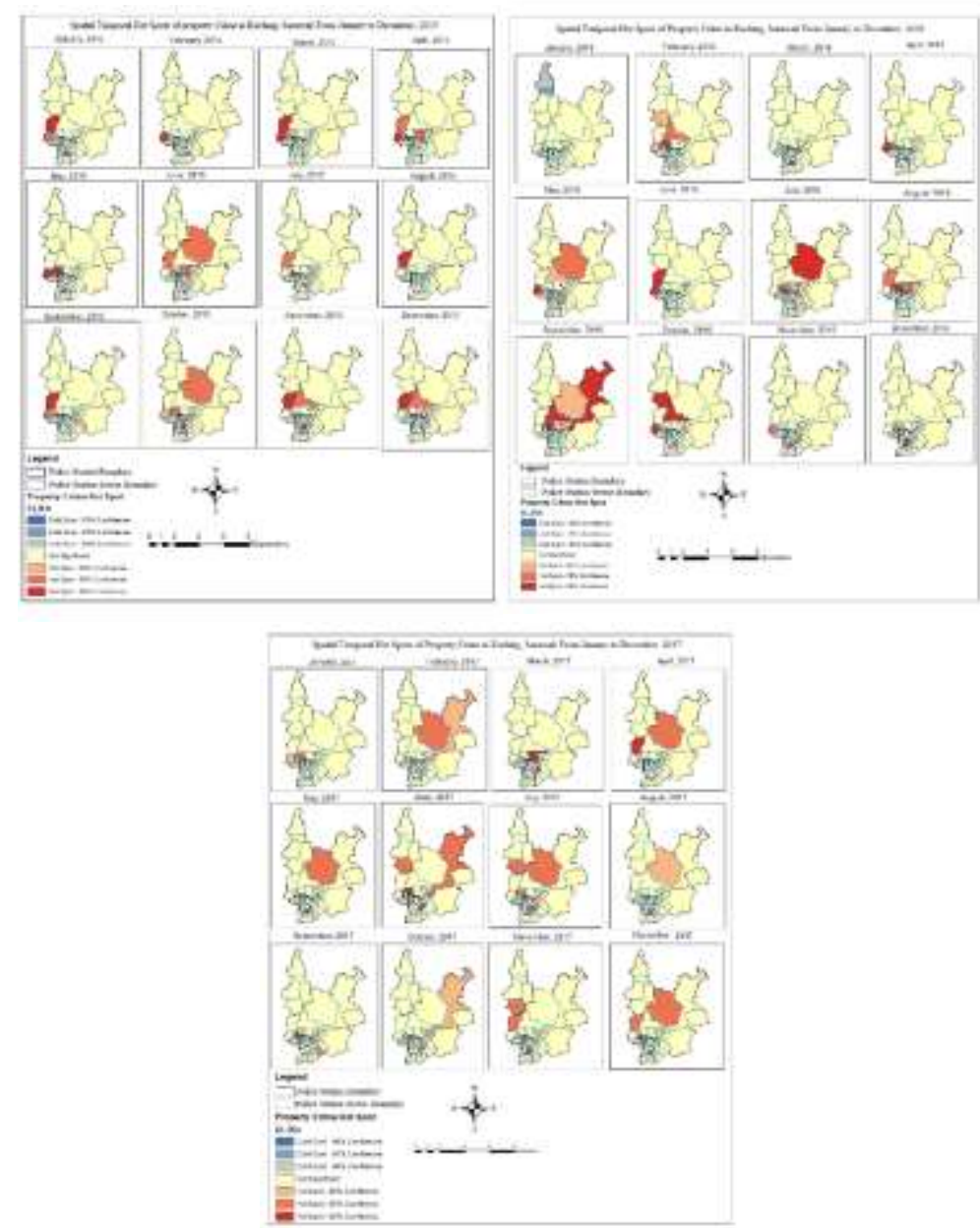

Figure 3: The Spatial Temporal Hot Spots of Property Crime in Kuching, Sarawak from January to December, 2015-2017

\section{DISCUSSION}

Getis Ord Gi* is able to identify monthly hot spots and cold spots across police station sector boundaries in Kuching, Sarawak that represents spatial clusters with significantly high or low property crime. Generally, in 2015, the hot spots of property crime are more likely to occur in April, May, June, September, and December. In 2016, hot spots tend to occur in February, May, July, and December, while in 2017 hot spots mostly occur in January, June, July, September to December. This indicates that hot spots of property crime in 
Norita Jubit, Tarmiji Masron \& Azizan Marzuki

Analyzing the Spatial Temporal of Property Crime Hot Spots. A Case Study of Kuching, Sarawak

Kuching, Sarawak tend to occur during the period of festivals and school holidays. This finding is supported by the theory of routine which states that shopping activities, school holidays and festival seasons are associated with crime due to residents in urban areas either leaving to go back to their hometown or going on vacation and this lead to the offender taking the opportunity to commit a crime (Cohn, 2000; Towers et.al, 2018).

Most holidays occur during festival seasons, such as Chinese New Year, Hari Raya, Hari Gawai and Christmas Day. This situation will also motivate offenders to commit crimes due to the increase of chance and suitable target. The previous study found that holidays and festivals are exogenous factors that might influence the incidents of crime (Lopez and Lauritsen, 2013). Most people from the urban areas would either go back to their hometown, spend more time outdoors, travelling, shopping or visiting their family and friends during the holidays which create crime seasonality. During the holidays, many premises such as schools, government offices and some business outlets will be closed. This routine activity leaves homes, offices and certain places empty and unguarded. (Cohn and Rotton, 2003). Hence, creating opportunities for criminal offences as those who are away indirectly make themselves an easy target to victimization.

\section{CONCLUSION}

The result of this study can be used by city planners and the Royal Malaysia Police (PDRM) to strategize and better monitor areas that are classified as hot spots of property crime. GIS information technology systems and criminal theory can shed insights on high-risk crime areas and provide better understanding in the phenomenon of property crime in Kuching, Sarawak. By using the Getis Ord Gi* technique, this study has been able to detect hot spots of property crime in Kuching Sarawak with statistically significant value in the spatial context.

\section{ACKNOWLEDGMENTS}

This paper was funded under Special Top-Down Grant (SPTDG) F06 / SpTDG / 1731/2018, Spatial Distribution, and Pattern of Drugs Addict and Crime: Case Study in Kuching and Penang, Universiti Malaysia Sarawak. The authors wish to express appreciation to Bukit Aman, Kuching District Police headquarters especially the Kuching Crime Investigation Department (CID) and the head of police stations in Kuching for giving cooperation.

\section{REFERENCES}

Andresen, M. A., Malleson, N. (2015). Intra-Week Spatial-Temporal Patterns of Crime. Crime Science, 4(12), 2-11.

Bold, M. \& Borg A. (2016). Evaluating Temporal Analysis Methods Using Residential Burglary Data. International Journal of Geo-Information, 5(148), 1-22. 
Borneo Post Online. Kegiatan Jenayah Tidak Akan Terhenti Walaupun Semasa Musim Perayaan. (2019). Retrieved June 15, 2017 from https://www.utusanborneo. com.my/2017/06/15/kegiatan-jenayah-tidak-akan-terhenti-walaupun-semasamusim-perayaan

Chen, Y., Li, Y. \& Li, J. (2016). Investigating the Influence of Tree Coverage on Property Crime: A Case Study in The City of Vancouver, British Columbia, Canada. The International Archives of the Photogrammetry, Remote Sensing and Spatial Information Sciences vol XLI-B2, Prague: Czech Republic. July 12-19, 2016.

Cohn, E. G. (2000). Weather, Seasonal Trends and Property Crimes in Minneapolis 19871988: A Moderator-Variable Time-Series Analysis of Routine Activities. Journal of Environmental Psychology, 20, 257-272.

Cozens, P., Saville, G. \& Hillier, D. (2005). Crime prevention through environmental design (CPTED): A Reviewand Modern Bibliography. Prop Manag, 23, 328-356.

Cohn, E. G. \& Breetzke, G. D. (2017). The Periodicity of Violent and Property Crime in Tshwane, South Africa. International Criminal Justice Review, 27(1), 60-71.

Cohn, E. G. \& Rotton, J. (2003). Even Criminals Take a Holiday: Instrumental and Expressive Crimes on Major and Minor holidays. Journal of Criminal Justice, 3(4), 351-360.

ESRI. (2011). GIS For Urban and Regional Planning. Redland: United State.

ESRI. (2019). GIS for Crime Analysis Building Better Analysis Capabilities with the ArcGIS Platform. Redland California: ESRI.

Fan, S. (2014). The Spatial-Temporal Prediction of Various Crime Types in Houston, TX Based on Hot Spot Techniques (Unpublished master dissertation). Central South University, Changsha, China.

Garnier, S., Caplan, J. M. \& Kennedy, L. W. (2018). Predicting Dynamical Crime Distribution from Environmental and Social Influences. Frontiers in Applied Mathematics and Statistics, 4(13), 1-10.

Ghani, Z. A. (2017). A Comparative Study of Urban Crime Between Malaysia and Nigeria. Journal of Urban Management, $\mathrm{xxx}(\mathrm{xxx}), 1-11$.

Guven, I. T. \& Gercek, D. (2018). Analysis of Distribution Pattern and Properties of Public Security Crimes in an Urban Environment: Case of İzmit City. Journal of Engineering Sciences and Design, 6(2), 265-272.

Kuching District Police Headquarters. (2018). Monthly Distribution of Property Crime From 2015-2017. Kuching, Sarawak.

Li, Y., Zhang, L., Yan, J., Wang, P., Hu, N., Cheng, W. \& Fu, B. (2017). Mapping the Hot spots and Cold spots of Ecosystem Services in Conservation Priority Setting. Journal of Geographical Sciences, 27(6), 681-696.

Lopez, K. C. \& Lauritsen, J. (2013). Seasonal Variation in Violent Victimization: Opportunity and the Annual Rhythm of the School Calendar. Journal of Quantitative Criminology, 29(3), 399-422

Luo, J. (2017). Multi-Spatiotemporal Patterns of Residential Burglary Crimes in Chicago: 2006-2016. ISPRS Annals of the Photogrammetry, Remote Sensing and Spatial Information Sciences, Volume IV-4/W2, Cambridge, USA, August, 7-9, 2017.

Martin, J. M. S., Gallego, J. I. R., Morato, R. B. (2019). Hot Spot Analysis Versus Cluster and Outlier Analysis: An Enquiry into The Grouping of Rural Accommodation in Extremadura (Spain). ISPRS, International Journal Geo-Int, 8(4), 176. 
Norita Jubit, Tarmiji Masron \& Azizan Marzuki

Analyzing the Spatial Temporal of Property Crime Hot Spots. A Case Study of Kuching, Sarawak

Muzafar Shah Habibullah \& Law, S. H. (2008). Property Crime and Macroeconomic Variables In Malaysia: Some Empirical Evidence From A Vector Error-Correction Model. MPRA. Paper 12112, University Library of Munich, Germany.

Matijosaitiene, I., Zhao, P., Jaume, S. \& Jr, J. W. G. (2019). Prediction of Hourly Effect of Land Use on Crime. International Journal of Geo-Information ispr, 8(16), 213 .

Mohd Nasir Desa \& Janusz, N. (1996). Temporal and Spatial Characteristics of Rainfall Kuala Lumpur, Malaysia. Atmospheric Research, 42(1-4), 263-277.

Marotta, P. (2017). Assesing Spatial Relationships Between Rates of Crime and Rates of Gonorrhea and Chlamydia in Chicago, 2012. J Urban Health, 276-288.

Mohd Ekhwan Toriman, Siti Nor Fazillah Abdullah, Izwan Ariff Azizan, , Mohd Khairul Amri Kamarudin, Roslan Umar \& Nasir Mohamad (2015). Spatial and Temporal Assessment on Drug Addiction Using Multivariate Analysis And GIS. Malaysian Journal of Analytical Sciences, 19(6), 1361-1373.

Mohd Shafiq Zakeyuddin, Amir Shahruddin Md Shah, Mohd Syaiful Mohammad, Nurul Fazlinda, Mohd Fadzil, Zarulhazrin Hashim \& Wan Maznah Wan Omar. (2016). Spatial and Temporal Variations of Water Quality and Trophic Status in Bukit Merah Reservoir, Perak. Sains Malaysiana, 45(6), 853-863.

Muhammad Amin Bughra, Mohammad Rahim Kamaluddin \& Geshina Ayu Mat Saat. (2014). A Trend Analysis of Violent Crimes in Malaysia. Health and The Environment Journal, 5(2), 41-56.

Norziha Che Him (2015). Potential for using climate forecasts in spatio-temporal prediction of dengue fever incidence in Malaysia (Unpublished Phd dissertation). University of Exeter, United Kingdom.

Nor-Ina Kanyo, Norizan Hj Md Nor, Ruslan Rainis, Ahmad Tarmizi Abdul Rahman dan Norita Jubit. (2017). Mengurus Ruang Jenayah: Suatu Tinjaun Dasar Pengurangan Jenayah di Malaysia. Geografia Malaysian Journal of Society and Space, 11(2), 107-117.

Norita Jubit, Tarmiji Masron, Mohd Norarshad dan Danggat Chabo. (2019). GIS Application in Identifying the Property Crime Hot Spot in Kuching, Sarawak. Malaysian Journal of Society and Space, 15(4), 30-49.

Siti Aekbal Salleha, Nur Suhaili Mansor, Zaharah Yusoff \& Rabiatul Adawiyah Nasir. (2012). The Crime Ecology: Ambient Temperature vs Spatial Setting of Crime (Burglary). Procedia Social and Behavioral Sciences, 42, 212-222.

Shamsuddin Shahid, Anil Minhans, Othman Che Puan, Sitti Asmah Hasan \& Tarmizi Ismail (2015). Spatial and Temporal Pattern of Road Accidents and Casualties in Peninsular Malaysia. Jurnal Teknologi, 76(14), 57-65.

Tarmiji Masron, Badaruddin Mohamed \& Azizan Marzuki. (2015). GIS Base Tourism Decision Support System for Langkawi Island, Kedah, Malaysia. Theoretical and Empirical Researches in Urban Management, 10(2), 21-35.

Tarmiji Masron, Danggat Chabo, Nur Faziera Yaakub, Ailis Elizabeth Epa, Ahmad Hata Rasit, Mohd Suhaidi Salleh, Shahrizal Hashim, Mohd Hairulnizam Mohd Zamri. (2020). Coronavirus (COVID-19) Post-Control Study of University Students: Case Study of Spatial Distribution of Universiti Malaysia Sarawak (UNIMAS) Students and National COVID-19 Cases. Centre for Spatially Integrated Digital 
Humanities, Faculty of Social Sciences and Humanities Universiti Malaysia Sarawak, Kota Samarahan, Sarawak.

Towers, S., Chen, S., Malik, A. \& Ebert, D. (2018). Factors Influencing Temporal Patterns in Crime in a Large American City: A Predictive Analytics Perspective. Plos One, 13(10), 1-27.

UNHABITAT. (2007). Enhancing Urban Safety and Security: Crime and Violence. United Nations Human Settlements Programme. Nairobi, Kenya.

Valente, R. (2019). Spatial and temporal patterns of violent crime in a Brazilian state capital: A Quantitative Analysis Focusing on Micro Places and Small Units of Time. Applied Geography, 103, 90-97.

Yar, P. \& Jamal Nasir. (2016). GIS Based Spatial and Temporal Analysis of Crimes, A Case Study of Mardan City, Pakistan. International Journal of Geosciences, 7, 325-334.

Zaini Nordin \& Nor Shah Mohd Saad. (2010). Ke Arah Bandar Selamat: Pencegahan Jenayah Bandar Melalui Perkongsian Pemetaan GIS Hot Spot Jenayah. Pusat Infrastruktur Data Geospatial Negara (MaCGDI) Kementerian Sumber Asli dan Aalam Sekitar (NRE). Putrajaya Malaysia.

World Bank. (2015). Achieving a System of Competitive Cities in Malaysia Main Report. Economic Planning Unit. Putrajaya, Kuala Lumpur.

Received: $15^{\text {th }}$ May 2020. Accepted: $1^{\text {st }}$ Sept 2020 